\title{
Jubileum významného českého historika, slavisty a balkanisty
}

\author{
Ivo Pospiśil (Brno)
}

Doc. PhDr. Václav Štěpánek, Ph.D., zástupce vedoucího Ústavu slavistiky Filozofické fakulty Masarykovy univerzity a předseda akademického senátu této fakulty oslaví v létě roku 2019 významné životní jubileum. Narodil se 31. 7. 1959 v Brně v rodině pozdějšího patriarchy Církve československé husitské Vratislava Štěpánka (1930-2013). V letech 1978-1983 studoval ruštinu a bulharštinu na FF UJEP v Brně, kde byli ze slavistů-filologů jeho učiteli mimo jiné Ivan Dorovský a Radoslav Večerka. Rok pracoval v brněnské kultuře, poté se stal redaktorem časopisu Věda a život (1986-1991; situaci v redakci popsal před časem ve sborníku Novinářem v Brně, 2011) a novinařinu hned neopustil: v letech 1991-1994 byl postupně redaktorem, sekretářem redakce a zástupcem šéfredaktora brněnské redakce Lidové demokracie, mezitím (1994-1998) také šéfredaktorem časopisu pro ochranu př́rody a krajiny Veronica. Novou etapu života zahájil po polovině devadesátých let: 1996-2002 byl lektorem češtiny na Bělehradské univerzitě, kde zažil bombardování letectvem NATO a napsal o tom velmi ceněnou knížku, a také externím vyučujícím na Ústavu slavistiky, kde se posléze zakotvil a stal se postupně asistentem, odborným asistentem a docentem (2011), čímž zatím vyvrcholila jeho akademická dráha, jež započala doktorátem filozofie (1988) a hodností Ph.D. (2003). To, co na docentu Václavu Štěpánkovi zaujme nejvíc, je řada oblastí, do nichž podstatně zasáhl: od členství a starostenství ve Slováckém krúžku, přes autorství a spoluautorství velkého počtu reprezentativních publikací z regionálních dějin (většinou s Liborem Janem), po členství ve výboru Matice moravské, členství v Srbské slavistické společnosti, ve vědeckém výboru sdružení Evropská kulturní stezka sv. Cyrila a Metoděje, členství v České asociaci slavistů a také Českém komitétu slavistů. Je také nositelem řady vyznamenání: je např̀ čestným členem Srbské slavistické společnosti (2013), nositelem Ceny Františka Alexandra Zacha za celoživotní přínos k rozvoji česko-srbských vztahů, kterou mu udělil Jihomoravský kraj v roce 2008, nositelem čestného uznání Srbské slavistické společnosti (Slavističko društvo Srbije) za významné výsledky na poli výuky slovanských jazyků a literatury a aktivitu v práci společnosti (2003) a to není zdaleka všechno. Kromě dlouholetého pobytu v Bělehradě a stáží v Bulharsku a Chorvatsku je zejména v poslední době zván na přednášky po celém Balkáně a v jiných zemích, kde se balkanistika pěstuje; známé jsou jeho vztahy k Vídeňské univerzitě; je respektován jako balkanista evropského a světového významu.

Všechny tyto aktivity v jejich dílčích i komplexních projevech zhodnotí jistě u př́ležitosti jeho jubilea jiní doma i v zahraničí, nás zajímá to, co je bezprostředně spjato se 
slavistikou a balkanistkou v širokém slova smyslu. Oblastí jeho vědeckého zájmu jsou dějiny jihoslovanských literatur, historie a kultura jihoslovanských národů, politologické aspekty moderních dějin jihoslovanských národů, novodobé dějiny jihoslovanských národů, slovanské literatury jako takové a areálová studia. Je členem oborových komisí doktorského studia Teorie a dějiny slovanských literatur a Filologicko-areálových studií, členem a předsedou komisí státních závěrečných zkoušek na řadě oborů balkanistiky a jihoslovanských filologií, ale také v programu historie, je školitelem řady doktorandů, to vše na Masarykově univerzitě, a kromě toho je členem oborové rady studijního programu Filologie v oboru Slovanské literatury na Filozofické fakultě Univerzity Karlovy.

Jako editor a koeditor působil při vydání proslulých česko-srbských sborníků Od Moravy k Moravě, Studia Balkanica Bohemo-Slovaca, edic z kolokvií Brno - Bělehrad v rámci Brněnských textů z filologicko-areálových studií, koeditoval sborníky z mezinárodních balkanistických sympozií, která se konala v Brně a spoluorganizoval je (2005, 2016).

Z jeho knižních publikací - kromě Zápisků z doby bombardování (red. Ivan Dorovský. 1. vyd. Brno: Společnost přátel jižních Slovanů, 1999) jsou to desítky studií a autorství knih a kapitol v knihách, mimo jiné Balkán po roce 1944, Současné Srbsko, Balkán a nacionalismus, Východní otázka, edice a spoluautorství sborníku z kolokvia Brno - Bělehrad Velká válka a areálové souvislosti. Kultura, literatura a kulturni historie slovanských národů (2014); byl koeditorem a spoluautorem Dějin Brna a hlavně je autorem spisu, jenž po českém vydání vyjde v zahraničí německy, a to Jugoslávie - Srbsko - Kosovo. Kosovská otázka ve 20. stoleti (Masarykova univerzita, 2011). Knihu jsem kdysi recenzoval v internetovém časopisu Proudy, nebot jako laik jsem si nemohl dovolit jakkoli hodnocení v odborném časopise. Pokud jsem měl výhrady, tak spíše k obecnému pojetí v dnešní české historiografii a politologii, nicméně nakonec jsem napsal: „Jako lačný čtenář, laik a amatérský zájemce hodnotím tedy Štěpánkovu knihu vysoce pozitivně, dưvody jsou nabiledni a jsou jistě sdíleny mnohými; moje hodnoceni je navic o to kladnější, oč více si uvědomuji komplementaritu tohoto opusu magnum, otázky, jež vyvolává, jeho otevřenost dalším strukturám a analýzám $i$ jiným oborům, které by vytvořily ještě širši a hlubši historický rámec. Štěpánkovou praci dosáhla podle mého soudu brněnská historická slavistika nebo slavistická historie, at’ již to tak někdo dovoli jmenovat nebo ne, a at’ už se sám autor s takovým vymezením identifikuje - jednoho ze svých vrcholü. Snad se i ukazuje, že oproti jednomu historickému minění lepši časy brněnská slavistika mèla, ale dobré časy (podle K. Čapka je nejuyšši hodnotou pozitiv) - a to jistě nejen historická, a nejen touto praci - však má a snad i nějakou dobu ještě mit bude. "1 Snad se v tom jako v kapce vody zrcadlí význam Štěpánkova díla, a to nejen tohoto.

1 Původní kniha o kosovské otázce: otazníky a vykřičníky (Václav Štěpánek: Jugoslávie - Srbsko - Kosovo. Kosovská otázka ve 20. století. Masarykova univerzita, Brno 2011, 471 s., ISBN 978-870-210-5476-9, ISSN 1211-3034). Proudy 1/2012. MK ČR E18200. ISSN 1804-7246 
V roce svého jubilea chystá doc. Štěpánek soubor svých studií a další knihu, připravuje se jeho festschrift; studenti obdivují jeho temperamentní přednášení, pokračuje ve studiu české menšiny na Balkáně, nepřestává působit v ekologickém hnutí, bádá v etnografii a regionální historii, o jeho roli v Slováckém krúžku nemluvě. Mnoga lěta!

prof. PhDr. Ivo Pospíšil, DrSc.

Ústav slavistiky

Filozofická fakulta, Masarykova univerzita

Arna Nováka 1, 60200 Brno, Česká republika

ivo.pospisil@phil.muni.cz 
